Presented at the Workshop on

Short Term Tests for Chemical

Carcinogens, August 22-24, 1979,

in Vancouver, B.C.

lun - r : : : i

DNA Synthesis Inhibition in Mammalian Cells as a

Test for Mutagenic Carcinogens

Robert B. Painter

Laboratory of Radiobiology

University of California

San Francisco, California 94143 


\section{Principle of Method}

Current models for the mechanism of action of mutagens begin with alterations in the structure of DNA, i.e., DNA damage. The general concept is that if DNA damage of any kind occurs there is a possibility that mutation may ensue, and therefore any agent that damages DNA is a potential mutagen. Because mutagenesis and carcinogenesis are closely correlated and because most, if not a11, mutagens are also carcinogens, it is safe to assume that any agent that causes DNA damage is also capable of inducing the process that eventually results in human cancer.

With these guiding principles in mind, I proposed a rapid test based on measurements of DNA synthesis rate in human cells in culture (Painter, 1977a). Agents that damage DNA cause lesions that can inhibit the overall rate of DNA replication by any of three mechanisms: 1) slowing the rate of DNA fork displacement, i.e., inhibiting the movement of the many growing points active at any one time in a human cel1;2) blocking the progression of DNA growing points already active in DNA replication (precocious termination); 3) blocking the initiation of those replicating units (replicons) normally scheduled to operate. Each of these mechanisms has been shown to occlir after various kinds of DNA damage, al though, to my knowledge, intercalating agents are the only DNA-damaging agents that slow fo. $k$ displacement rates (Painter, 1978). Precocious termination appears to be the major mechanism by which agents such as 47 traviolet 1 ight and $\mathrm{N}$-acetoxyacetoaminofluorene act (Regan and Setlow, 1973), and the inhibition of replicon initiation is the main mechanism for the inhibitions of DNA sjnthesis caused by $X$ rays (Makino and Okada, 1975; Painter and Young, 1975) and methyl methanesulfonate (Painter, 1977a; Dahle et al., 1978).

Irrespective of the mechanism by which these agents inhibit DNA synthesis, they share the common feature that the DNA damage remains even after the 
damaging agent itself is gone. The rate of DNA synthesis continues to decrease as a function of time after the initial damage as more and more of the total genome becomes involved with the lesions, at leart until repair processes intervene. It is this feature of continuing depression in rate of DNA synthesis that distinguishes the action of DNA-damaging agents from the action of substances that inhibit the rate of DNA synthes is but do not cause DNA damage. Nondamaging agents (e.g., the protein synthesis inhibitors cycloheximide and puromycin) cause their effects only when in contact with

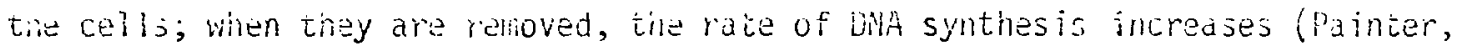
$1977 b)$.

This difference in the rate of DNA synthesis after treatment is the basis of the mammalian cell ONA synthesis inhibition test. Cells (usually HeLa) are exposed to the agent for an arbitrarily chosen exposure time of $30 \mathrm{~min}$ for agents that do not require metabolic activation and 60 min for those tinat do. After the agent is removed and washed from the cells, the rate of DNA replication is measured immediately in treated and control cells. This is repeated at 0.5 and $1.5 \mathrm{hr}$ after removal of the agent. Data are plotted as percentage of control rate of DNA synthes is as a function of time. A curve showing a decreasing rate of DNA synthes is between 0 and $0.5 \mathrm{hr}$ or between 0.5 and $1.5 \mathrm{hr}$ is considered to be diagnostic of a DNAdamaging agent. A curve showing an increasing rate of DNA synthesis between 0 and $0.5 \mathrm{hr}$ is considered diagnostic of an agent that inhibits DNA synthesis but does not cause DNA damage. The damage to DNA caused by some agents seems to be repaired so rapidly that a curve showing a drop in rate of DNA synthes is during the first $0.5 \mathrm{hr}$ followed by recovery during the period Fig. I between 0.5 and $1.5 \mathrm{hr}$ is sometimes observed (Fig. 1). If this observation is repeatable, the agent is still considered a DNA-damaging agent, e.g., ethyleneimine $\left(10^{-4} \mathrm{M}\right)$ and benzidine $\left(6 \times 10^{-4} \mathrm{M}\right)$ (Painter, 1978). 
Thus far, no agent has been found that reproducibly produces an increasing rate of DNA synthesis between 0 and $0.5 \mathrm{hr}$ and a decreasing rate after $0.5 \mathrm{hr}$.

\section{Test Organism and Testing Protocol}

About $10^{5}$ HeLa (or other rapidly growing mammalian) cells are inoc' 1 ated into $35 \mathrm{~mm}$ petri dishes containing $5 \mathrm{ml}$ of Eagle's minimum essential medium and $0.01 \mu \mathrm{Ci} / \mathrm{ml}$ of $\left[{ }^{1 / 4} \mathrm{C}\right]$ chymidine (50 nCi/mmole). The ceits are incubatad in a humidified $5 \% \mathrm{CO}_{2}$ atmosphere for $24 \mathrm{hr}$ or longer, the radioactive medium is removed from the cells, and a new medium is added that contains either the compound under test or an equivalent amount of carrier material; e.g., because some compounds must be dissolved in dimethyl sulfoxide, an equivalent amount of dimethyl sulfoxide is used in the medium for the control cultures. The compounds under test are incubated with the cells for $30 \mathrm{~min}$; if, however, the compound must be activated by the liver microsomal extract S-9 (Ames et al., 1975), the incubation is for $1 \mathrm{hr}$. The medium containing the compound is then removed from all cells, and the cells are washed twice with minimum essential medium. Fresh medium is added to all cultures except four; to these cultures (two controls and two treated) is added a medium containing $20 \mu \mathrm{Ci} / \mathrm{ml}$ of $\left[{ }^{3} \mathrm{H}\right]$ thymidine $(50 \mathrm{Ci} / \mathrm{mmole})$. After a 10 -min incubation the radioactive medium is removed and the cells are washed rapidly with ice-cold SSC $(0.15 \mathrm{M}$ sodium chloride-0.015 M sodium citrate). The cells are scraped into cold SSC and filtered through whatman GF/C filters wetted with ice-cold $4 \%$ perchloric acid; the filters are then washed with $4 \%$ perchloric acid, $70 \%$ alcohol, $95 \%$ alcohol, and $100 \%$ alcohol, dried, and counted with a liquid scintillation spectrometer.

One-half hour after removal of the drug, the medium on a second set of four cultures is removed and the cells are incubated with $\left[{ }^{3} H\right]$ thymidine 
and prepared for counting. At $1.5 \mathrm{hr}$ after removal of the drug, the entire operation is repeated. Because the cells had previously incorporated $\left[{ }^{14} \mathrm{C}\right]$ thymidine into parental DNA, the final counts are recorded as the ratio, ${ }^{3} \mathrm{H} /{ }^{14} \mathrm{C}$, which is a measure of specific activity of the ${ }^{3} \mathrm{H}$ and therefore of the rate of DNA synthesis. The ${ }^{3} \mathrm{H} /{ }^{14} \mathrm{C}$ ratios for drug-treated cells are expressed as percentages of control inc poration into DNA as a function of time of incubation after end of treatment.

If nothing is known about the agent to be tested, the highest possible concentration is used first. If the agent inhibits DNA synthesis very strongly (greater than about $40 \%$ ) or causes cell dislodgement, the concentration must be systematically reduced until a satisfactory zero-time inhibition is found. Previous experience or published reports on the agent or on similar agents sometimes aid in choosing a useful concentration of the agent for testing.

If the agent fails to inhibit DNA synthesis at the highest concentration, metabolic activation must be attempted; the agent is added to S-9 Mix (Ames et al., 1975) and the mixture is incubated with the cells for $1 \mathrm{hr}$. S-9 Mix is derived from a microsomal preparation from the liver of rats previously injected with Aroclor, a polychlorinated biphenyl (Ames et al., 1975), and is commercially available. The mixture is made up as follows:

Solution 1, prepared fresh each time, contains $3 \mathrm{ml}$ of $0.125 \mathrm{M}$

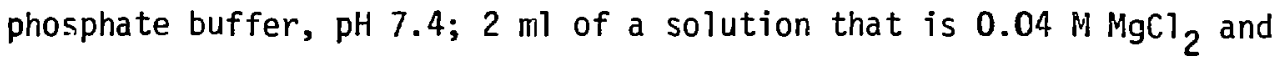
$0.165 \mathrm{M} \mathrm{KCl}, 0.05 \mathrm{~m}$ ? of $1 \mathrm{Mglucose}-6-$ phosphate, and $0.4 \mathrm{ml}$ of $4.2 \times 10^{-2}$ M NADP.

Solution 2 contains $2 \mathrm{ml}$ of freshly thawed liver extract plus $9 \mathrm{ml}$ ố Solution 1 .

The final solution to be added to cells contains the agent diluted in McCoy's 5A medium plus Solution 2. For unknown agents, the ratio is $7.5 \mathrm{ml}$ of McCoy's to $2.5 \mathrm{ml}$ of Solution 2; however, for most agents a 
$9: 1$ ratio is sufficient. Controls are made up in the same way but contain only the carrier (dimethyl sulfoxide, water, etc.). A positive control should be included with each test of unknowns. As an example of an agent that does not require metatolic activation, 4-nitroquinoline 1-oxide gives reproducible resilts. For an agent: that requires metabolic activation, benzo(a)pyrene has proved valuable.

\section{Evaluation of Results}

To estimate the relative potency of the agent, a particular endpoint must be chosen. The concentration that produces a $40 \%$ inhibition of DNA synthesis (i.e., to $60 \%$ of control value) within $2.5 \mathrm{hr}$ was originally used, but after screening of 50 to 60 compounds, it seems that the concentration necessary to inhibit DNA synthesis to $60 \%$ of control within only $1.5 \mathrm{hr}$ is more advantageous.

Table $1 \quad$ The results with the first 25 agents tested (Table 1) were previously reported (Painter, 1977a,b; 1978); these agents had good correlation with the Ames test (Painter and Howard, 1978). About 30 more agents have been tested since those reports and the DNA synthesis inhibition test continues

Table 2 to detect those agents known to damage DNA (Table 2). As yet no false positives have been observed. Ascorbate is positive in the test (Galloway and Painter, 1979), as it is in the Ames test (Guttenplan, 1977) and in the unscheduled DNA synthesis test (Stich et al., 1976). It seems, therefore, that ascorbate is capable of causing DNA damage, although normal levels of catalase, which protects intracellular DNA from ascorbate-induced damage, may prevent this action in vivo. Very weak mutagens may not be detectable by the test; e.g., saccharin is negative although it has been reported to be positive in the sister chromatid exchange test (Wolff and Rodin, 1978). 
is its speed. Strongly positive compounds that do not require metabolic activation can be identified within about $3 \mathrm{hr}$ after their addition to the cells. If the protocol of testing high concentrations without S-9 followed by testing with S-9 is used, even those compounds requiring metabolic activation can, theoretically, be identified within one day. of course, as with any testing procedure, the test must be reproduced before it can definitely be considered positive. Negatives generally require more testing, and even after three or four runs at the highest possible concentration $t$. compound can only be reported negative in this particular test.

Another advantage of the test is its cost. 0ther than the scintillation counter, which is an instrument found in nearly all biology and biochemistry laboratories, the materials are all easily obtained and inexpensive. And the growing of HeLa cell cultures and preparation of samples for the assay are procedures that do not require advanced training or specialized techniques.

The DNA synthesis inhibition test is a more reliable indicator of DNA damage than the unscheduled DNA synthesis test, which is completely insensitive to intercalating agents (Painter, 1978) and relatively poor at detecting agents that damage DNA in a manner similar to $X$ rays (Rasmussen and Painter, 1966; Painter and Young, 1972; Regan and Setlow, 1974). The DNA synthesis inhibition test is very sensitive to intercalating agents such as adriamycin (Painter, 1978) and actinomycin D (Table 2). Moreover, replicon initiation is uniquely sensitive to $X$ rays (Makino and 0kada, 1975; Painter and Young, 1975); therefore, inhibition of overall DNA replication by $X$ rays is easily detected' after doses of about 250 rads (Painter, 1978), whereas doses of 5000 rads or more are required before unscheduled DNA synthesis can routinely be observed (Rasmussen and Painter, 1966; Painter and Young, 1972; Fox and Fox, 1973). 
The test is based on DNA damage and therefore is not meant to detect agents (such as asbestos) that induce cancers by other mechanisms. The test is also subject to the same uncertainties as other tests using in vitro metabolic activation; another microsomal preparation (e.g., from a tissue other than liver or from liver stimulated by another inducer) may yield different results. Combining this in vitro HeLa test with an in vivo (whole mouse) DNA synthes is inhibition test (Friedman and Staub, 1976; Amlacher and Rudolph, 1978), in which metabolic activation inherently occurs but which is more laborious to perform, may constitute a valuable screening method for DNA-damaging agents.

\section{Acknowledgements}

I thank Ricci Howard for performing these assays, Lynn Haroun, Drs. Bruce Ames and Sidney Stolzenberg for furnishins chemicals, and Drs. Ron Hart and Bernie Daniels for HPLC-purified DMBA, 5FDMBA, and 2FDMBA. Work supported by the U.S. Department of Energy. 


\section{$\underline{\text { References }}$}

Ames, B.N., McCann, J., and Yamasaki, E. (1975). Methods for testing carcinogens and mutagens with the Salmonella/mammalian-microsome mutagenicity tesi. Mutat. Res. 31:347-364.

Amlacher, E. and Rudolph, C. (1978). [Nuclear DNA synthes is rate and labelling index: effects of carcinogenic and non-carcinogenic chemicals on its behaviour in the organism of growing CBA-mice. The thymidine-incorporation-screening-system (TSS)] (In German). Exp. Path. 16:69-82.

Dahle, D.B., Griffiths, T.D., and Carpenter, J.G. (1978). Inhibition of deoxyribonucleic acid synthesis and replicon elongation in mammalian cells exposed to metnyl methanesulfonate. Molec. Pharmacol. 14:278289.

Fox, M. and Fox, B.W. (1973). Repair replication in X-irradiated lymphoma cells in vitro. Int. J. Radiat. Biol. 23:333-358.

Friedman, M.A. and Staub, J. (1976). Inhibition of mouse testicular DNA synthesis by mutagens and carcinogens as a potential simple mamalian assay for mutagenesis. Mutat. Res. 37:67-76.

Galloway, S.M. and Painter, R.B. (1979). Vitamin C is positive in the DNA synthesis inhibition and sister-chromatid exchange tests. Mutat. Res. 60:321-327. Guttenplan, J.B. (1977). Inhibition by L-ascorbate of bacterial mutagenesis induced by two $\mathrm{N}$-nitroso compounds. Nature 268:368-370.

Makino, F. and Okada, S. (1975). Effects of ionizing radiations on DNA replication in cultured marmalian celis. Radiat. Res. 62:37-51. 
Painter, R.B. (1977a). Inhibition of initiation of HeLa cell replicons by methyl methanesulfonate. Mutat. Res. 42:299-304.

Painter, R.B. (1977b). Rapid test to detect agents that damage human DNA. Nature 265:650-651.

Painter, R.B. (1978). DNA synthesis inhibition in HeLa cells as a simple test for agents that damage human DNA. J. Environ. Path. Toxicol. $2: 65-78$.

Painter, R.B. and Howard, R. (1978). A comparison of the Hela DNA-synthesis inhibition test and the Ames test for screening of mutagenic carcinogens. Mutat. Res. 54:113-115.

Painter, R.B. and Young, B.R. (1972). Repair replication in mammalian cells after X-irradiation. Mutat. Res. 14:225-235.

Painter, R.B. and Young, B.R. (1975). X-ray-induced inhibition of DNA synthesis in Chinese hamster ovary, human HeLa, and mouse L cells. Radiat. Res. 64:648-656.

Rasmussen, R.E. and Painter, R.B. (1966). Radiation-stimulated DNA synthesis in cultured mammalian cells. J. Cell Biol. 29:11-19. Regan, J.D. and Setlow, R.B. (1973). Repair of chemical dankage to human DNA. In: Chemical Mutagens; Principles and Methods for Their Detection, vol. 3, A. Hollaender (Ed.), Plenum Press, New York, pp. 151-170. Regan, J.D. and Setlow, R.B. (1974). Two forms of repair in the DNA of human cells damaged by chemjcal carcinogens and mutagens. Cancer Res. $34: 3318-3325$.

Stich, H.F., Karim, J., Koropatnick, J., and Lo, L. (1976). Mutagenic action of ascorbic acid. Nature 260:722-724.

Wolff, S. and Rodin, B. (1978). Saccharin-induced sister chromatid exchanges in Chinese hamster and human cells. Science 200:543-545. 
Table 1. Concentrations of chemicals required to inhibit HeLa DNA synthesis by $40 \%$ within $2.5 \mathrm{hr}$

S-9

Chemical

required?
Effective dose

(M)

\begin{tabular}{|c|c|c|}
\hline $\mathrm{N}$-acetoxy-2-acetylaminofluorene (AAAF) & No & $1.0 \times 10^{-7}$ \\
\hline Adriamycin & Ho & $1.0 \times 10^{-6}$ \\
\hline Aflatoxin $B_{1}$ & Yes & $5.0 \times 10^{-8}$ \\
\hline Benzidine & No & $6.0 \times 10^{-4}$ \\
\hline Benzo(a!pyrene & Yes & $7.0 \times 10^{-6}$ \\
\hline Busulfan & No & $>2.5 \times 10^{-2}$ \\
\hline Cycloheximide & - & Negative \\
\hline Cyclophosphamide & Yes & $6.0 \times 10^{-4}$ \\
\hline Dimethylnitrosamine & Yes & $1.0 \times 10^{-1}$ \\
\hline Dimethyl sulfoxide (DMSO) & - & Negative \\
\hline Ethyleneimine & No & $1.0 \times 10^{-4}$ \\
\hline Ethyl methanesulfonate (EMS) & No & $1.0 \times 10^{-2}$ \\
\hline Hydroxyurea & - & Negative \\
\hline ICR-170 $\quad \because$ & No & $5.0 \times 10^{-8}$ \\
\hline Methyl methanesulfonate (MMS) & No & $5.0 \times 10^{-4}$ \\
\hline$N$-methyl-N'-nitro-nitrosoguanidine (MNNG) & No & $2.0 \times 10^{-6}$ \\
\hline Mitomyc in $\mathrm{C}$ & No & $1.0 \times 10^{-6}$ \\
\hline Natulan & - & Negative \\
\hline Nickel chloride & - & Negative \\
\hline 4-Nitroquinoline 1-oxide & No & $2.0 \times 10^{-7}$ \\
\hline Phorbol ester & - & Negative \\
\hline Potassium cyanide & - & $\begin{array}{l}\text { Negative } \\
\text { (continued) }\end{array}$ \\
\hline
\end{tabular}


Painter - 12

Table 1 (continued)

S-9

Chemical

required?
Effective dose

(M) $3^{\prime} 3^{\prime} 5^{\prime} 5^{\prime}-$ Tetramethylbenz idine

Trenimon

Triethylenemelamine (TEM)
$-$

NO

No
Negative

$2.0 \times 10^{-7}$

$1.0 \times 10^{-4}$ 
Table 2. Chericals tested in the mammalian cell DNA synthesis inhibition test since last report (Painter, 1978)

S-9

Chemical

required?
Effective dose ${ }^{a}$

(M)

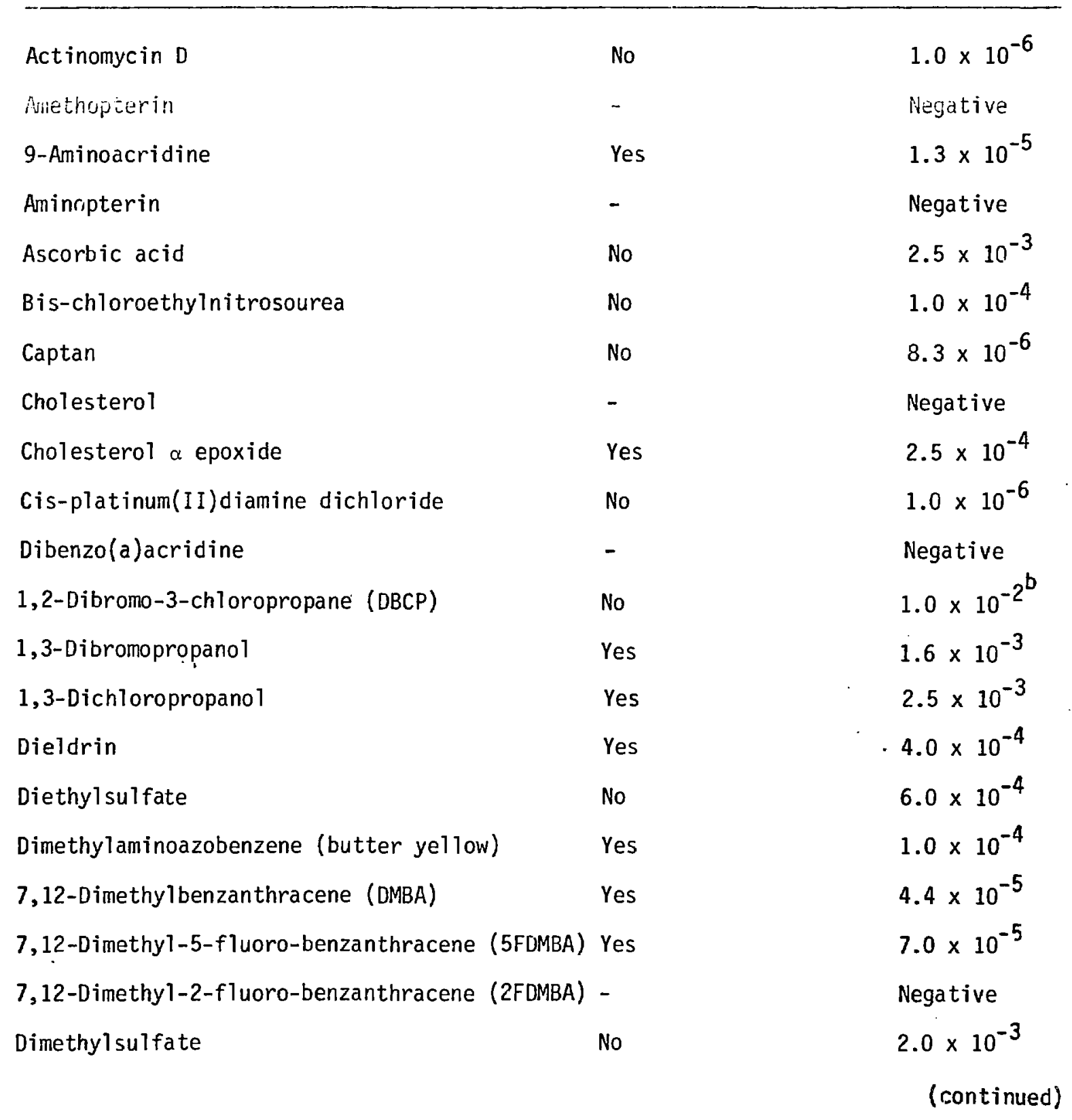


Table 2 (continted)

S-9

Chemical
Effective dose

(M)
Epibromohydrin

Frichtoronytion

Ethylnitrosourea

MechToroethamine $\mathrm{HCl}$

Methyinitrosourea

B-Naphthylamine

Saccharin

Thio-TEPA

Vincristin
No

No

No

No

No

Yes

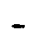

No

$-$
$1.5 \times 10^{-3^{b}}$

$2.7 \times 10^{-3^{b}}$

$1.0 \times 10^{-4}$

$1.0 \times 10^{-6}$

$5.0 \times 10^{-5}$

$2.1 \times 10^{-4}$

Negative

$5.0 \times 10^{-3}$

Negative

${ }^{a}$ Dose required to inhibit DNA synthesis to $60 \%$ of control within 90 min after end of treatment.

berformed with Chinese hamster ovary cells instead of HeLa cells. . 


\section{Painter - 15}

Fig. 1. Inhibition of HeLa DNA synthes is by 9-aminoacridine (9A) and benzo(a)pyrene (BP). Both chemicals were dissolved in dimethyl sutioxide and incubated with HeLa cells in the presence of S-9 Mix (Ames et al., 1975) for $1 \mathrm{hr} . \quad \mathrm{O}-\mathrm{O}, 9 \mathrm{~A}\left(2.6 \times 10^{-6} \mathrm{M}\right) ; \Delta-\Delta, 9 \mathrm{~A}\left(7.8 \times 10^{-6} \mathrm{M}\right)$; $\odot-9 A\left(1.3 \times 10^{-5} \mathrm{M}\right) ; \nabla \cdots, \mathrm{\nabla}, \mathrm{BP}\left(4 \times 10^{-5} \mathrm{M}\right)$. 


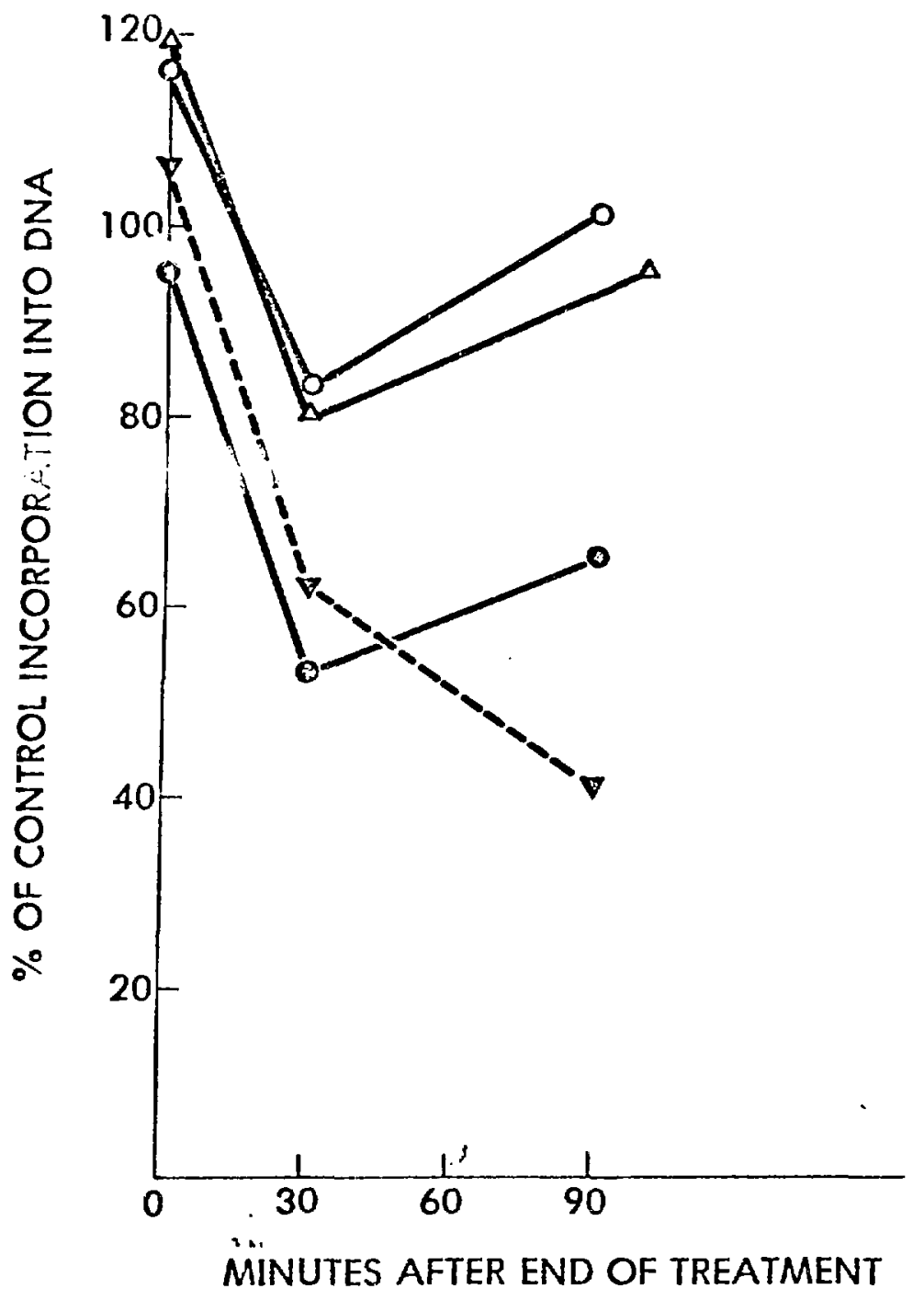

a:

Fig. 1 